\title{
MAGNETIC CHARACTER OF THE BRAZILIAN CONTINENTAL SHELF AND UPPER SLOPE*
}

\author{
ROBERTO FAINSTEIN**, JOHN D. MILLIMAN***, and HARDY JOST****
}

\begin{abstract}
The general magnetic character of the Brazilian continental shelf and slope has been defined on the basis of 35,000 line $\mathrm{km}$ of magnetic data collected in 1972-73. Anomaly patterns on the shelf and upper slope south of Vitoria suggest that most underlying structures are related to seaward extensions of continental features. In contrast, many of the magnetic anomalies on the continental margin between Abrolhos Plateau and northeastern Brazil seem to be related to oceanic structures, particularly seamounts and fracture zones. Magnetic anomalies off the Amazon probably originated prior to the rifting of South America from Africa.
\end{abstract}

RESUMO As feiçzes magnéticas gerais da plataforma e talude continental do Brasil foram definidas com base em $35000 \mathrm{~km}$ de perfis magnéticos, realizados em 1972-73. No setor situado ao sul de Vitória, as anomalias magnéticas da plataforma e da parte superior do talude são correlacionáveis às feiçðes estruturais da margem continental. Em contraste, muitas das anomalias da plataforma, entre Abrolhos e a região nordeste, parecem relacionadas com as estruturas oceânicas, de modo especial com as elevações submarinas e zonas de fratura. Na costa amazônica, as anomalias parecem ligadas à separação da América do Sul e África.

INTRODUCTION Brazil has the longest north-south coastline in the world $\left(5^{\circ} \mathrm{N}\right.$ to $34^{\circ} \mathrm{S}$ ), and yet until recently, the geology of offshore Brazil was poorly knownt, in order to document the morphology, oceanography and structure of the Brazilian continental shelf, slope and rise, Project REMAC (Global Reconnaissance Survey of the Brazilian Continental Margin) was established in 1972. The project is conducted jointly by the Woods Hole Oceanographic Institution (WHOI), Petróleo Brasileiro S/A (Petrobrás), Companhia de Pesquisa de Recursos Minerais (GPRM), Departamento Nacional da Produção Mineral (DNPM), Conselho Nacional de Desenvolvimento Científico e Tecnológico (CNPq) and Diretoria de Hidrografia e Navegação do Ministério da Marinha do Brasil (DHN/MM).

As a part of this program, a preliminary geological and geophysical survey of the Brazilian continental shelf and upper slope was made aboard the R/V Professor Besnard (Instituto Oceanográfico, Universidade de São Paulo). This survey, lasting from November 18, 1972 to April 8, 1973, covered a total of more than $35,000 \mathrm{~km}$ (Fig. 1), during which time bathymetric, seismic, magnetic and oceanographic measurements were made and bottom sediment and suspended matter samples were collected. The purpose of this paper is to present a general picture of the magnetic patterns of the Brazilian shelf and upper slope as delineated from the data collected during this cruise.

METHODS Magnetic measurements weie made with a towed proton-precession Varian magnetometer, model V-75. The sensor fish was towed at a depth of 10 to $15 \mathrm{~m}$ below the sea surface and approximately 80 to $100 \mathrm{~m}$ behind the ship. Magnetic values were

* Contribution Number 3284 of the Woods Hole Oceanographic Institution

** Petróleo Brasileiro S/A (Petrobrás), Rio de Janeiro, Brasil

***Woods Hole Oceanographic Institution, Woods Hole, Mass., EUA

****Universidade do Rio Grande do Sul, Porto Alegre, Rio Grande do Sul, Brasil

†Except for unpublished information from Petrobrás 
Figure 1-Track of N/O Professor W. Besnard during the nearshore phase cruises off Brazil, November 15, 1972 to April 6, 1973
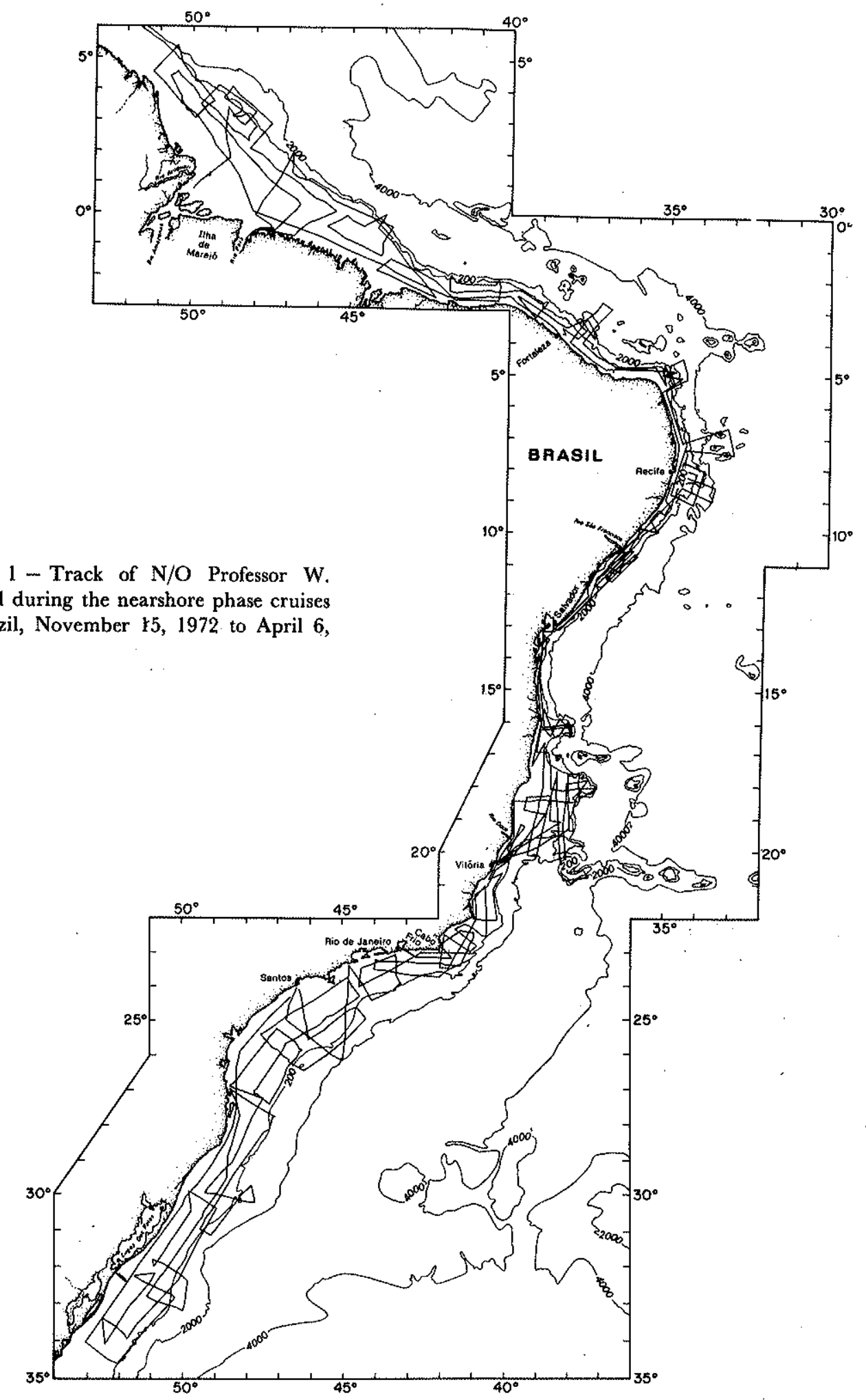
read every $15 \mathrm{~min}$ (a horizontal interval of 3 to $4 \mathrm{~km}$ ) and digitized on to standard Fortran coding forms. No attempt was made to correct for diurnal variations although in some parts of the South Atlantic variations can reach as much as 80 gammas. Such diurnal variations may explain several instances in which the calculated magnetic anomalies of intersecting tracks did not agree with one another. On the other hand, navigational errors may also account for some lack of agreement.

Ship's navigation was provided mostly by a combination Magnavox satellite receiver and a Hewlett-Packard mini-computer. An average of 15 fixes were received each day, with an estimated accuracy of $\pm 400 \mathrm{~m}$ for each fix. Due to problems with the receiver, navigation during much of the work south of $28^{\circ} \mathrm{S}$ was restricted to celestial fixes, dead reckoning and nearshore radar fixes.

Data processing involved the removal of the normal field in order to obtain the magnetic anomaly for each digitized point. The normal field was deduced from 1965 estimates (Cain et al., 1964, 1965; IAGA, 1969) and the ship's navigation.

The track lines in some instances were sufficiently close to one another to provide reasonably accurate maps (particularly in the Amazon area, off Sergipe-Alagoas and in the area south of Itajaí). Perhaps because of the closely-spaced data patterns, or perhaps because of the regional geology, each of these areas displays magnetic anomalies which correlate with known or suspected geological features. In contrast, many areas lack the necessary data control to allow us to delineate meaningful geological patterns. However, as data from other cruises (both past and future) are processed and incorporated into this picture, regional patterns in these areas should become more clear.

MAGNETIG FRAMEWORK OF BRAZIL Southern Brazil The southern Brazilian continental margin is characterized by positive magnetic highs which are normally less than 150 gammas in amplitude (Fig. 3). South of Porto Alegre the anomalies parallel the shelf break and values generally are less than +100 gammas, but locally exceed 300 gammas. Practically no negative anomalies occur in this area. This smooth pattern probably reflects the thick sedimentary sequence of the offshore extension of the Pelotas basin in Rio Grande do Sul State (Fig. 2).

This pattern of smooth and gentle anomalies changes abruptly north of Porto Alegre (Figs. 3 and 4). Anomalies immediately seaward of Porto Alegre are characterized by relatively short wavelength and low amplitude highs and lows. Most probably these anomalies represent a seaward extension of faults within the Torres Syncline (Fig. 2).

North of Porto Alegre the magnetic anomalies display two distinct patterns. Nearshore anomalies have short wavelengths and high amplitudes (Figs. 4 and 5); amplitudes exceed 1700 gammas. These features probably are caused shallow-buried igneous bodies. North of Santos this nearshore pattern becomes linear, trending northeast and extending into the late Precambrian granitic formations of Rio de Janeiro city.

The outer shelf between Porto Alegre and Rio de Janeiro is characterized by the same broad wavelength and gentle anomaly patterns seen in the south (Figs. 3 and 4). Most probably this pattern reflects the thick sedimentary cover present throughout the outer shelf and slope as well as the lack of magnetic intrusives.

Southeastern Brazil The magnetic pattern east of Rio de Janeiro city is complex and more difficult to relate to local geological features. The area is characterized by a series of alternating magnetic highs and lows, the highs having short wavelengths and high amplitudes and the lows having long wavelengths and low amplitudes. A steep-sided anomaly trending 
Figure 2:- Generalized tectonic map of coastal Brazil, showing major sedimentary basins (cross-hatched) and general tectonic lineations. From DNPM (1971). The geographic boundaries of the following magnetic charts are shown

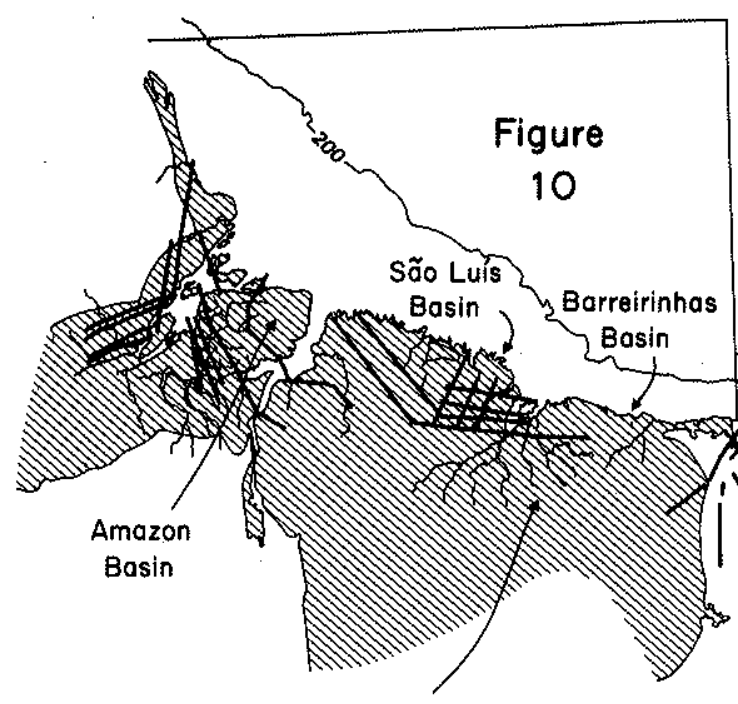

Maranhão Basin

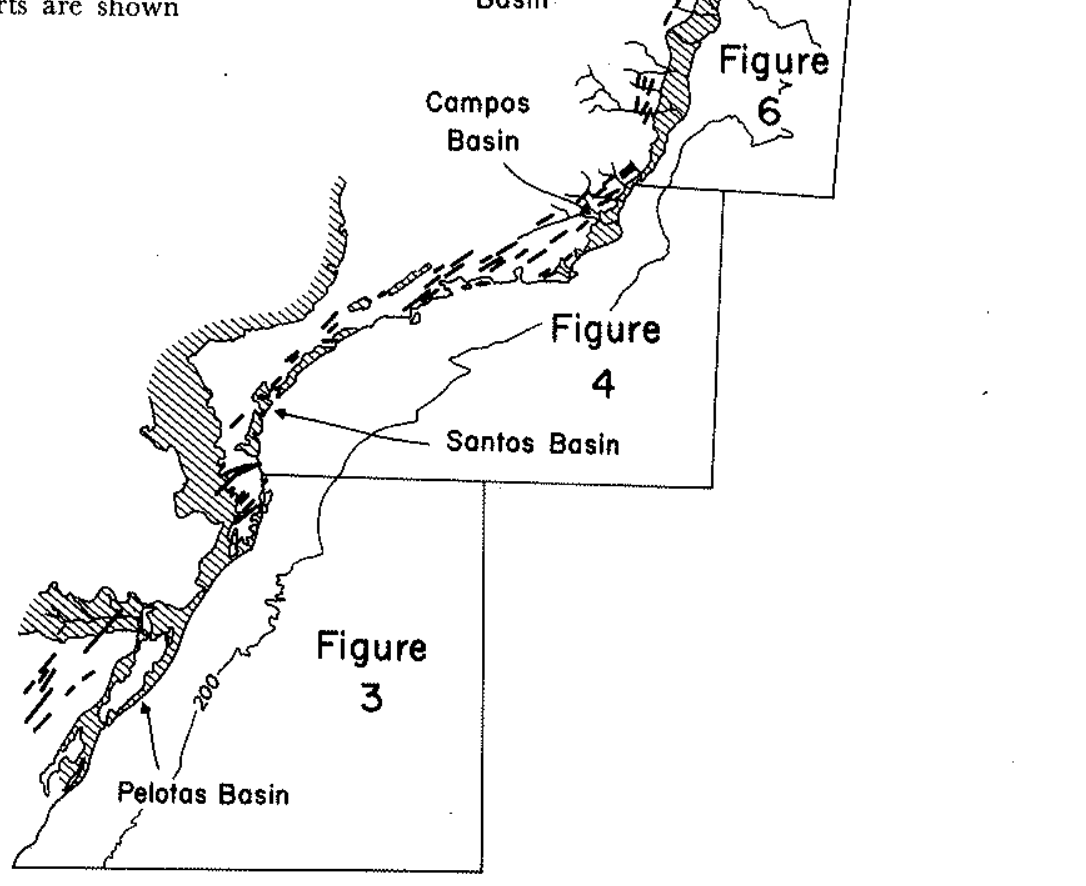




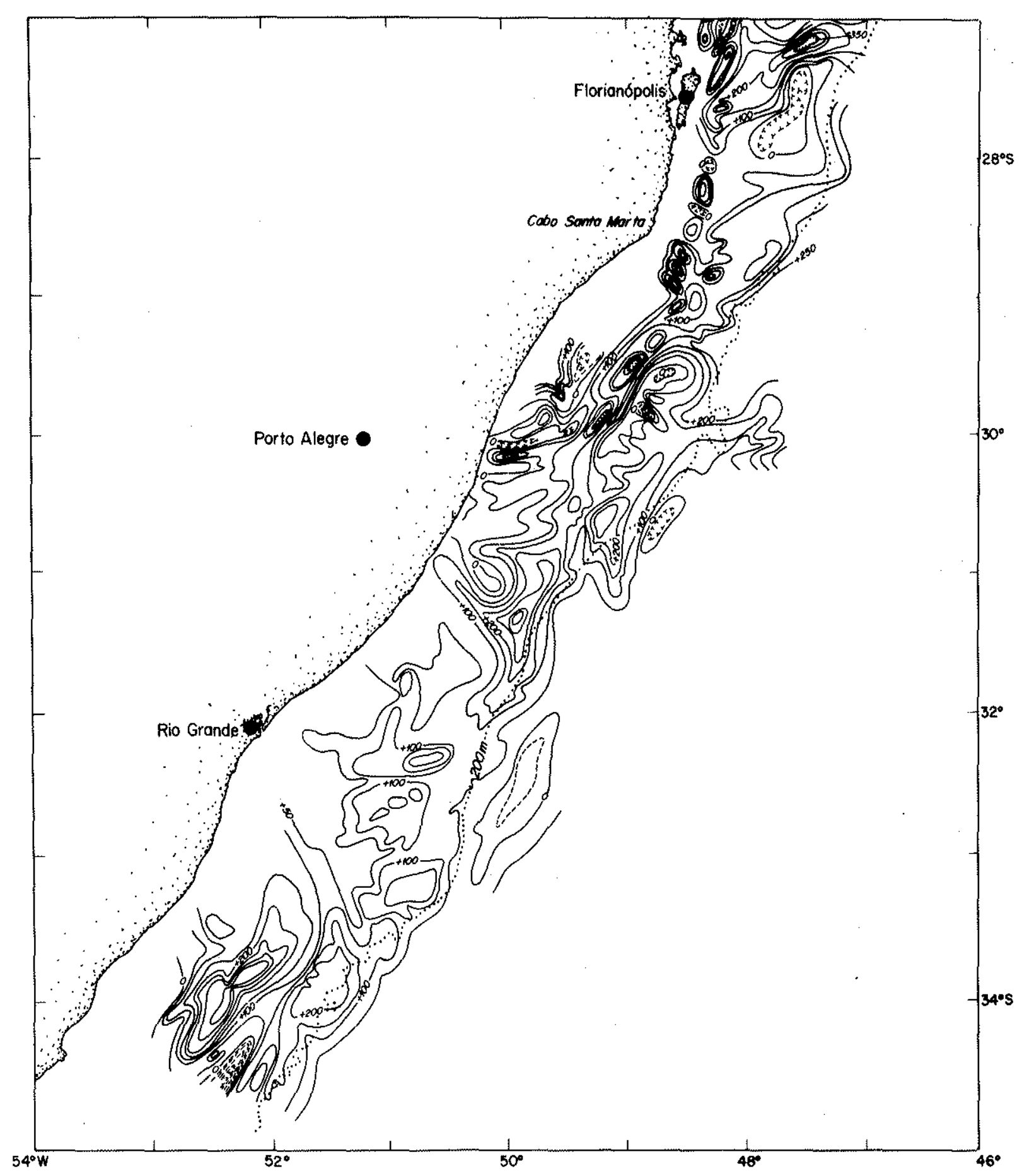

Figure 3 - Magnetic anomalies (in gammas) off southern Brazil, from the Brazil-Uruguay border to Florianópolis 


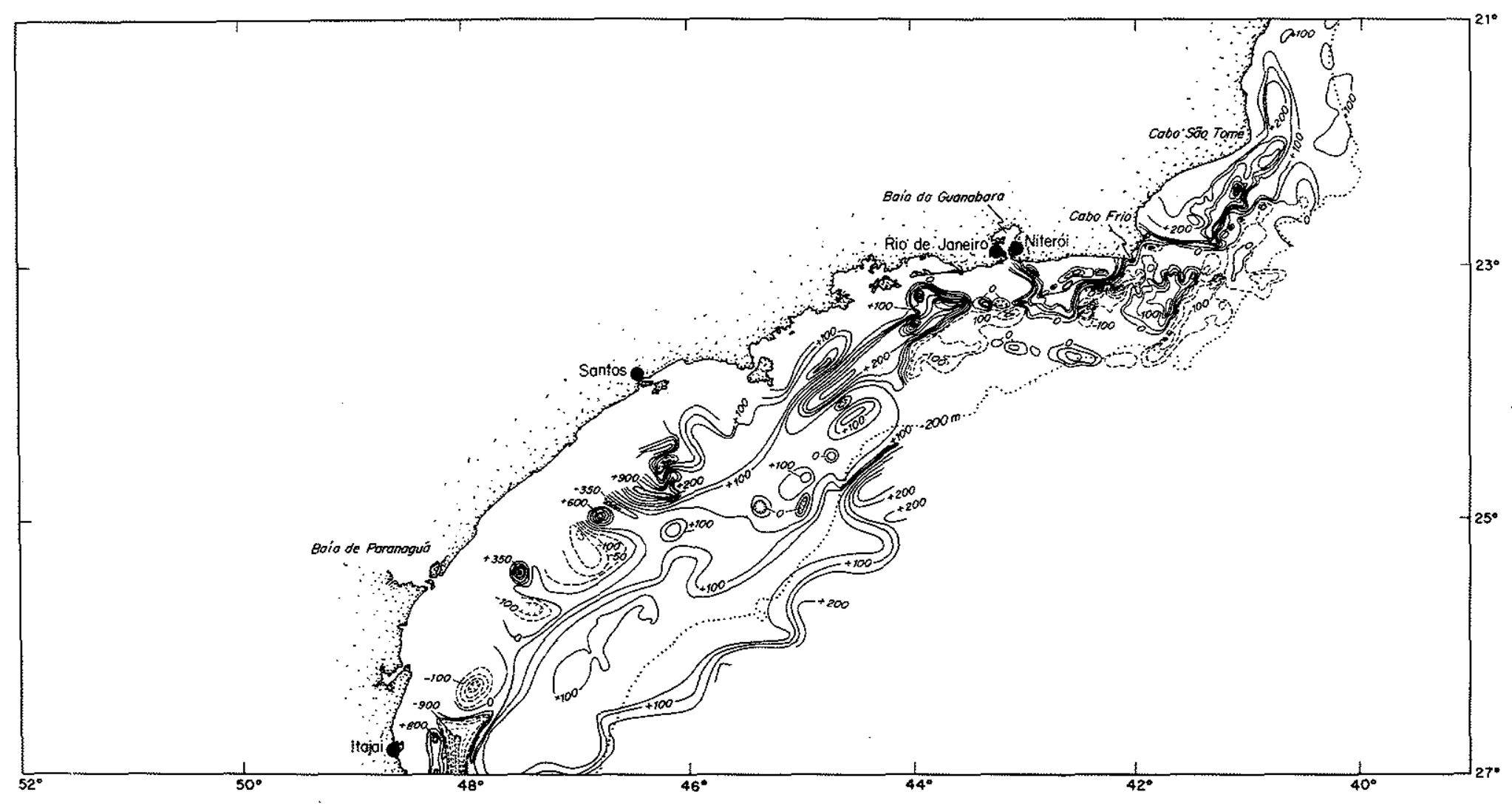

Figura 4 - Magnetic anomalies (in gammas) off southern Brazil, from Itajai to Cabo São Tomé 
LINE 1-H (Osório Area)

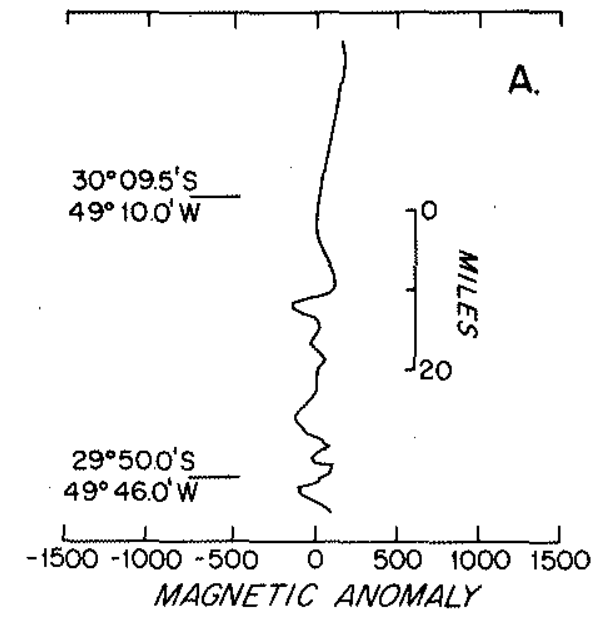

LINE 27 (S̃̃o Paulo)

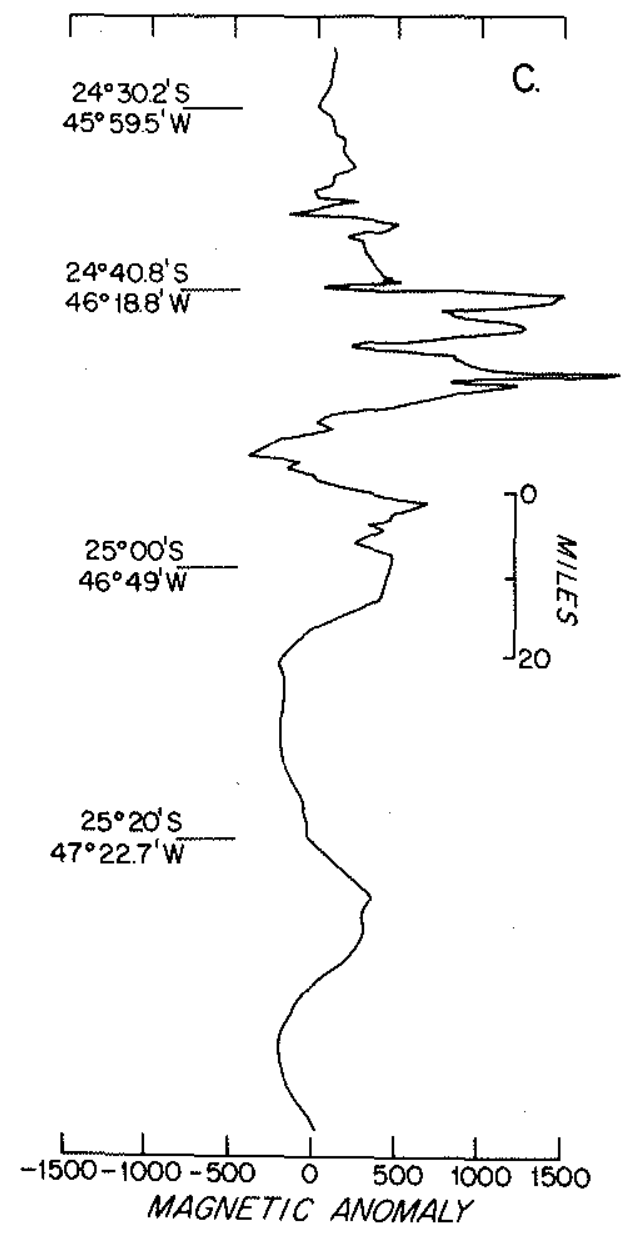

LINE 25 (ltajaí)

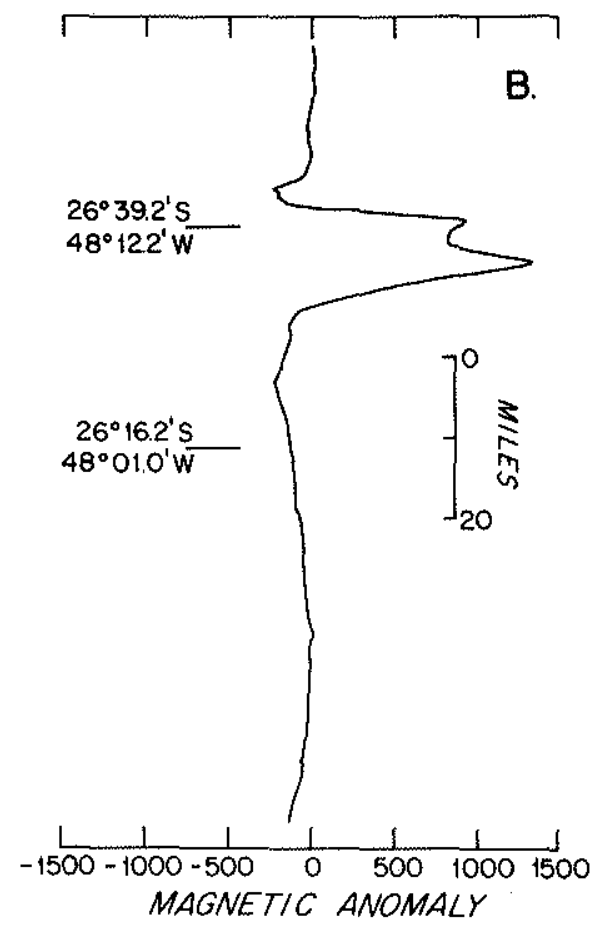

L.INE 221 (Cabo Frio)

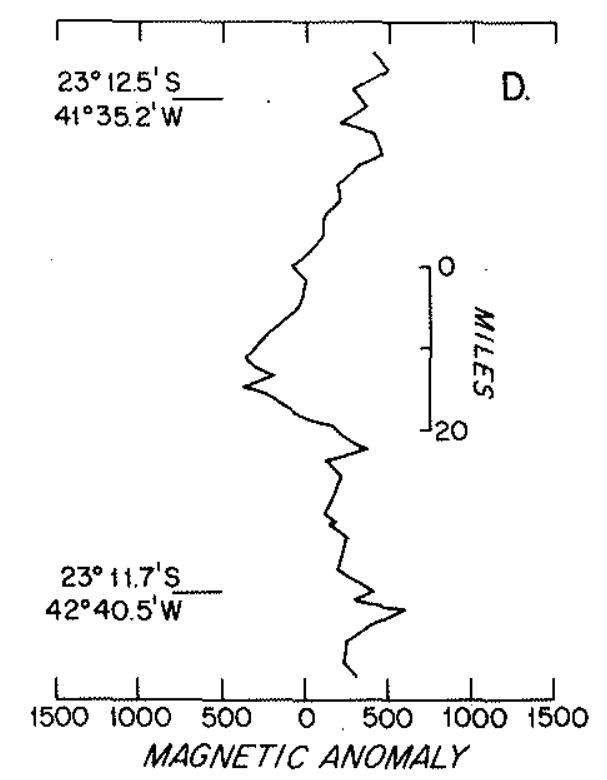

Figure 5 - Magnetic anomaly profiles off southern Brazil 
normal to the coast line just north of Cabo Frio (Fig. 4) may represent a major structure. perhaps a fault or the edge of a sedimentary basin.

The shelf and slope between Cabo São Tomé and Vitória is characterized by very broad and low amplitude magnetic anomalies, generally less than 100 gammas (Figs. 4 and 6). This subdued magnetic pattern may be the result of a thick sedimentary sequence, although present geological data indicate that sedimentary thicknesses on the adjacent shoreline are less than $1000 \mathrm{~m}$ (DNPM, 1971).

Abrolhos Region The Abrolhos-Royal Charlotte Bank complex is the dominant geomorphic feature on the continental margin between Vitória and Salvador (Fig. 1). The magnetic character of these features is very different from that of the southern shelf. First, we find some major negative anomalies, the most prominent of which separates two prominent magnetic highs on Abrolhos Plateau between 18 and $19^{\circ} \mathrm{S}$ (Fig. 6). Second, Abrolhos and Royal Charlotte Bank are characterized by numerous short wavelength highs and lows, with values generally not exceeding \pm 250 gammas (Fig. 7). The magnetic anomalies

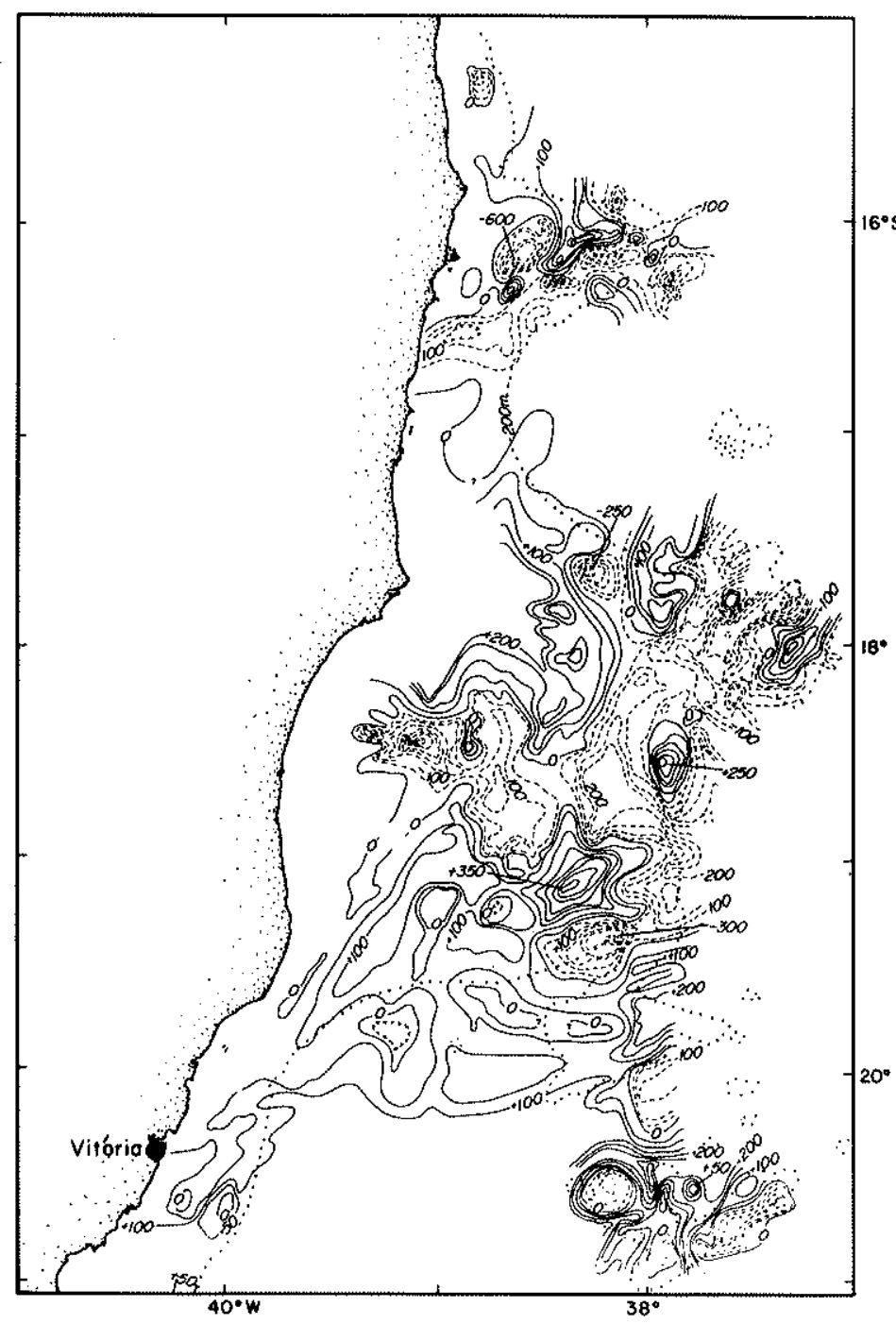

Figure 6 - Magnetic anomalies (in gammas) on Abrolhos Plateau and Royal Charlotte Bank 
LINES 65,67 (Abrolhos Bank)

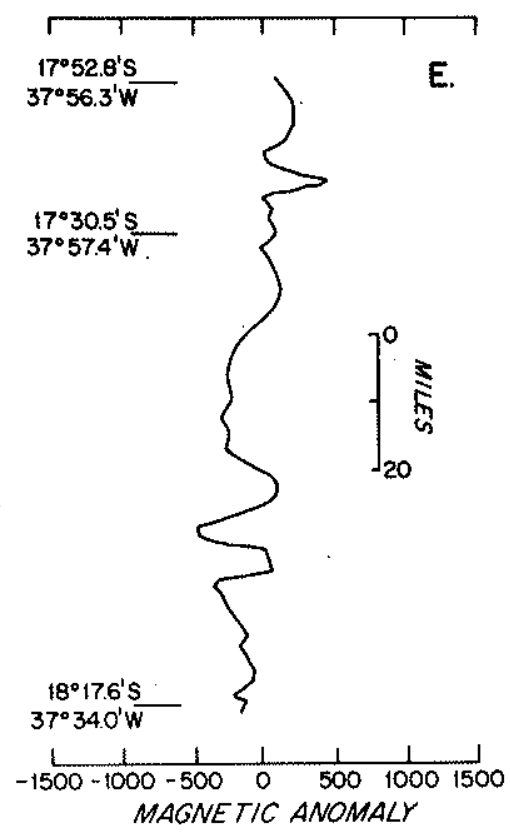

LINES $57,58,59$ (Western Abrolhos)

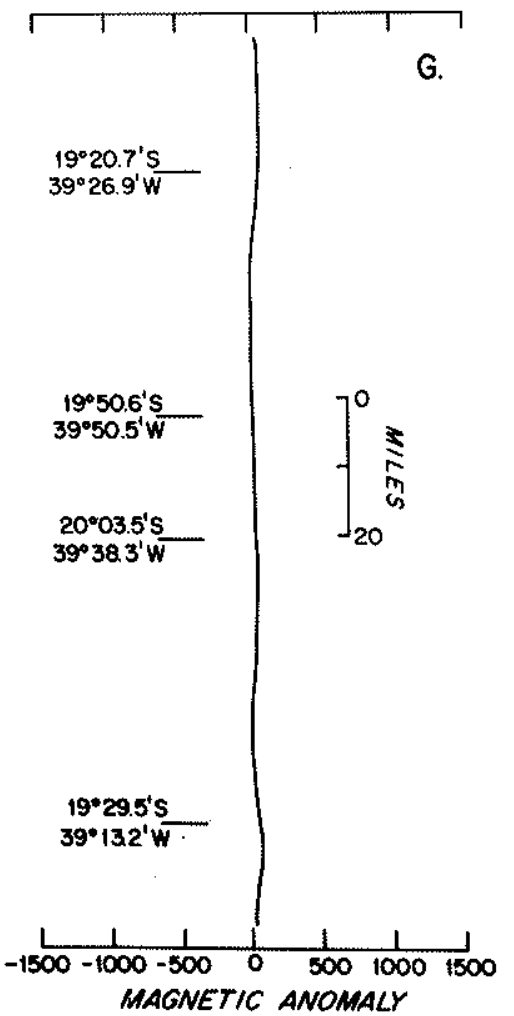

LINE 201 (Southeast Abrolhos)

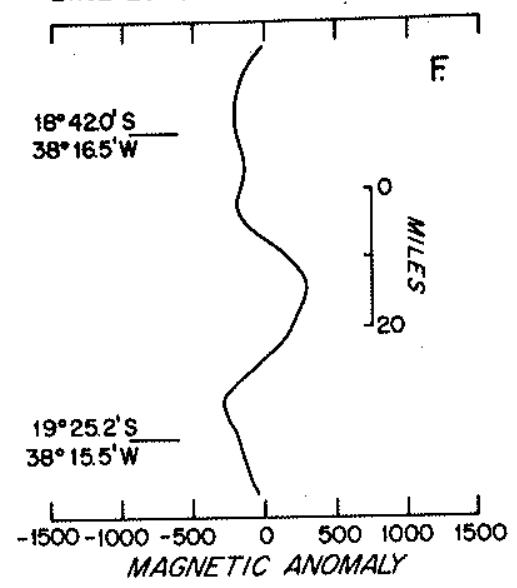

LINES 72,73,74 (Royal Charlotte Bank)

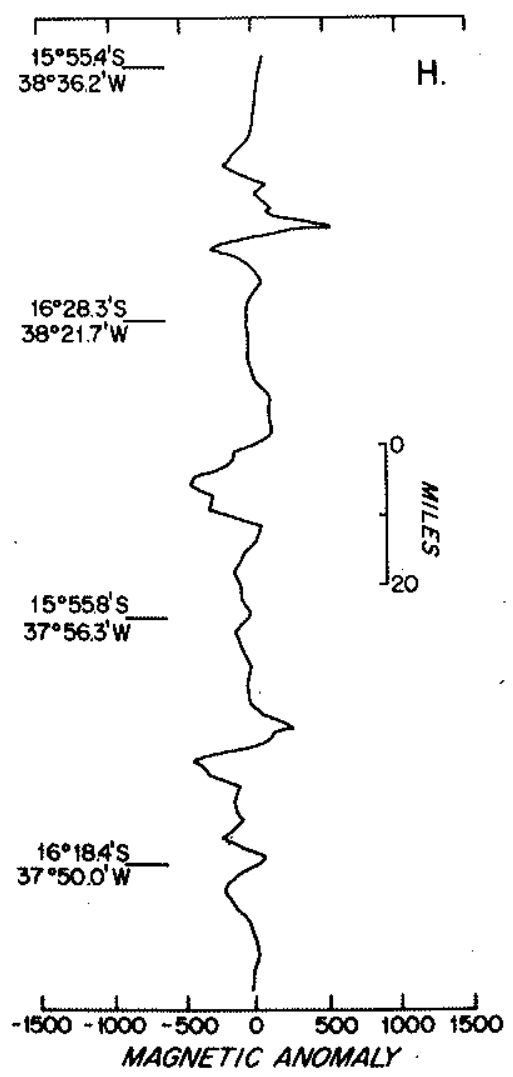

Figure 7 - Magnetic anomaly profiles from Abrolhos Plateau and Royal Charlotte Bank 
coincident with the offshore banks, such as Banco Vitória, Banco Ghamplain and Banco Montague, are undoubtedly indicative of an igneous origin. The anomaly patterns over Abrolhos Plateau, however, are more difficult to explain. Are they related to buried seamounts over which sediments have accreted, or are the anomalies related to post-depositional intrusion or faulting? The geometry and trend of the linear magnetic highs and lows may suggest a structural control, and unpublished seismic refraction and reflection data collected by Petrobrás suggest that basic intrusives are not common.

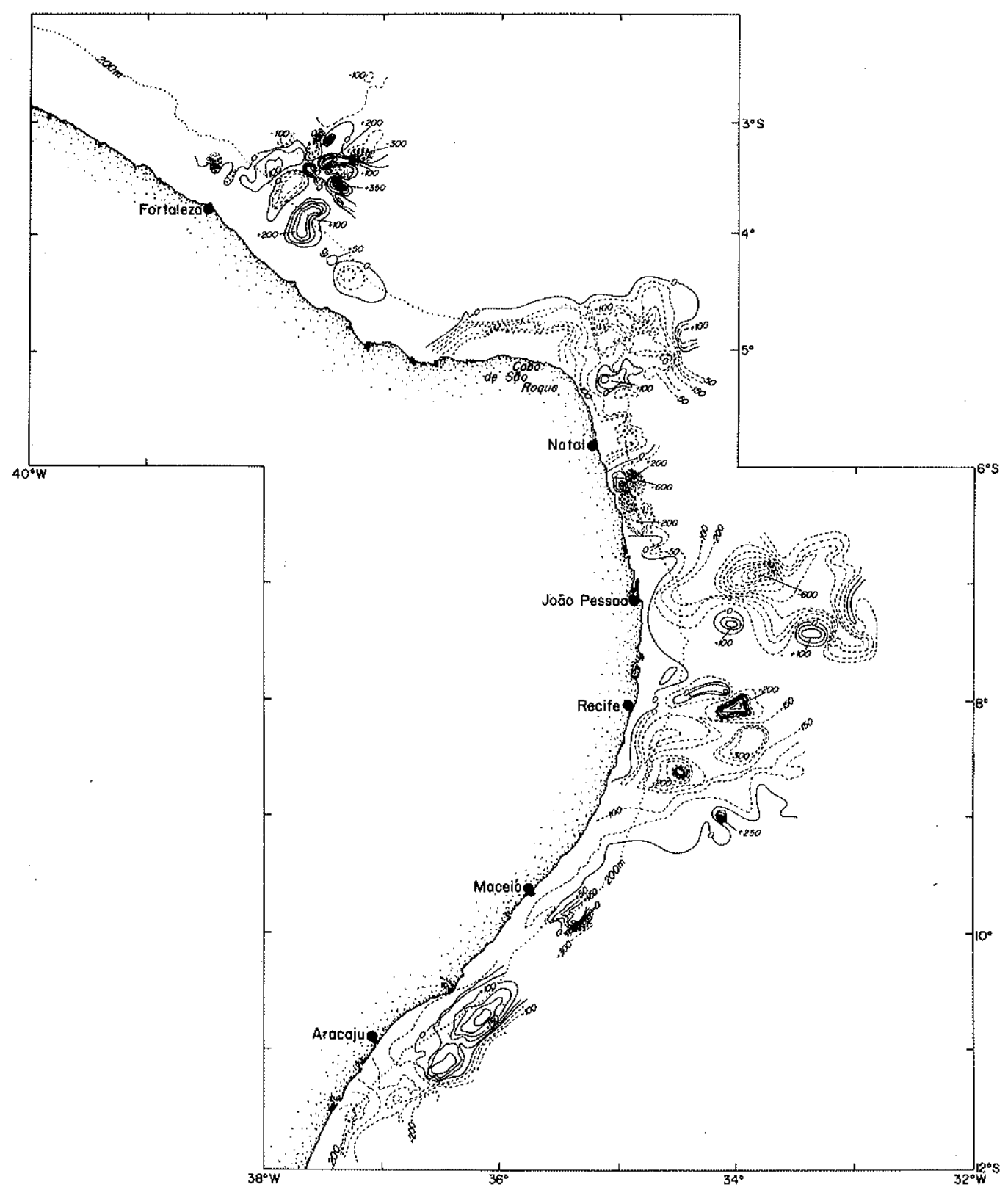

Figure 8-Magnetic anomalies (in gammas) off eastern and northeastern Brazil 
Northeastern Brazil At present we do not have sufficient magnetic data from the narrow shelf and slope between 12 and $15^{\circ} \mathrm{S}$ to permit construction of an anomaly map. Although the continental margin north of $12^{\circ} \mathrm{S}$ remains narrow, we have collected a sufficient number of profiles to delineate the magnetic character of the outer shelf and upper slope. Off both Aracaju and Maceió, we find major slope anomalies with well-developed highs $(+200$ gammas) followed on the seaward side by negative values in excess of -200 gammas (Fig. 8 ). We have not connected these two slope anomalies because of the lack of sufficient data, but we suspect that they represent a continuous magnetic feature (Summerhayes, Fainstein, and Ellis, in preparation). Landward of the slope anomalies, the magnetic pattern is relatively smooth, with low-amplitude and slightly negative values.

Negative anomalies become prominent over much of the shelf and slope north of Maceio. Whether this pattern indicates actual negative fields or systematic deviations from the 1965 estimates of Cain et al. (1965) is not known. The shelf just south of Natal is characterized by several major local negative anomalies. These may be related to down-faulted blocks, as delineated by structural exploration (Petrobrás, unpublished data). At present, however, we cannot say whether these anomalies lie within the westward continuation of the Recife-João Pessoa basin which lies between 6 and $8^{\circ} \mathrm{S}$, or is a southward extension of the Potiguar basin (Fig. 2).

The Pernambuco Plateau, seaward of Recife, exhibits several major magnetic anomalies, most of which are positive, rising above a generally negative background (Figs. 8 and 9). These localized anomalies may well be magnetic signatures of seamounts behind and around which the sediments composing the Pernambuco Plateau accumulated. Other anomalies associated with seamounts are seen seaward of João Pessoa, although at least one major anomaly ( -600 gammas) does not coincide with any known topographic high.

With the exreption of one localized positive anomaly, the area off Cabo de São Roque is characterized by negative anomalies. This pattern may indicate a seaward extension of the Potiguar basin, with its limits perhaps delineated by the magnetic high which occurs along the middle slope. More data are needed in this area, however, in order to delineate clearly the boundaries of the basin.

While the data between Fortaleza and Cabo de São Roque are sparse, preliminary analysis suggests that this area has à generally subdued magnetic character. The Ceará Plateau on the slope off Fortaleza, on the other hand, is characterized by isolated peaks of positive and negative anomalies (Fig. 9). Most of the positive peaks can be correlated with seamounts extending eastward from the Fernando de Noronha Chain.

North Brazil The magnetic anomalies west of Fortaleza $\left(40\right.$ to $\left.44^{\circ} \mathrm{W}\right)$ tend to be smooth with low amplitudes. A magnetic high on the shelf between 40 and $41^{\circ} \mathrm{W}$ probably is related to the presence of igneous rocks drilled in this area (Kazumi Miura, personal communications, 1972). These rocks lie on a linear trend coincident with the proposed intersection of the Romanche Fracture Zone and the continental margin (Francheteau and Le Pichon, 1972).

On the shelf west of Baía de São Marcos, the magnetic anomalies are generally negative, with some sporadic positive values (Figs. 9 and 10). The perpendicular trend of anomalies with respect to the coast line characterizes the Amazon shelf between Baía de São Marcos and Cabo Norte. The anomalies are generally regular short-wavelength features with amplitudes of 200 to 300 gammas. This pattern corresponds closely with a series of grabens and horsts which cut the shelf between 44 and $46^{\circ} \mathrm{W}$ (Rezende and Ferradaes, 1971). Other data from Petrobrás (Schaller et al., 1971) also indicate major horst-graben structures over much of the Amazon shelf (Fig. 2). The anomalies at 48 and $50^{\circ} \mathrm{W}$ may 
LINE 98 (Pernambuco Plateau)

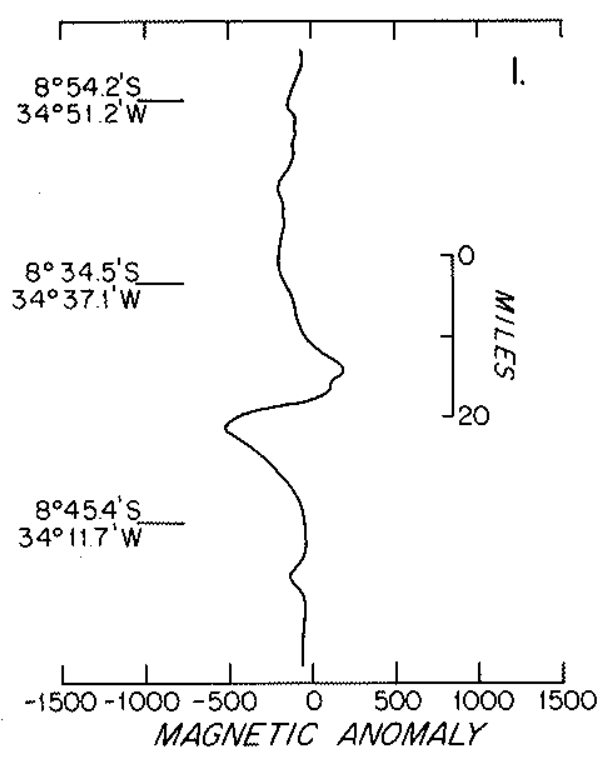

LINE 122 (Cearó Plateau)

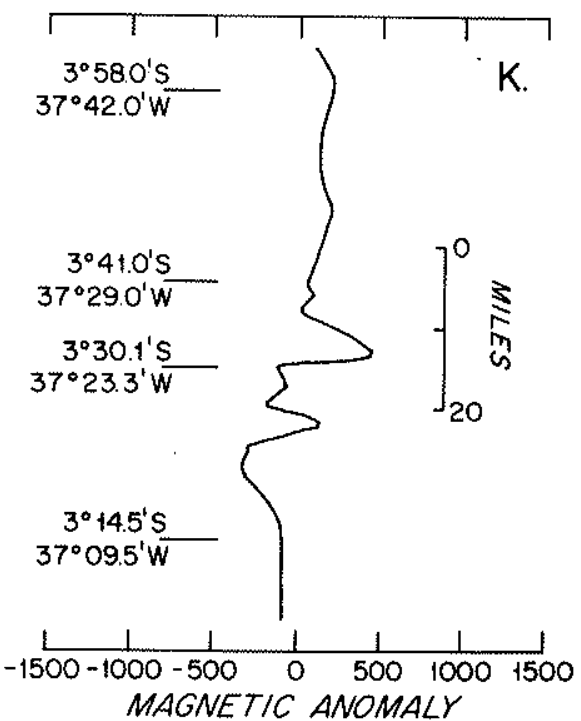

LINE 110 (Rio Grande do Norte Plateau)

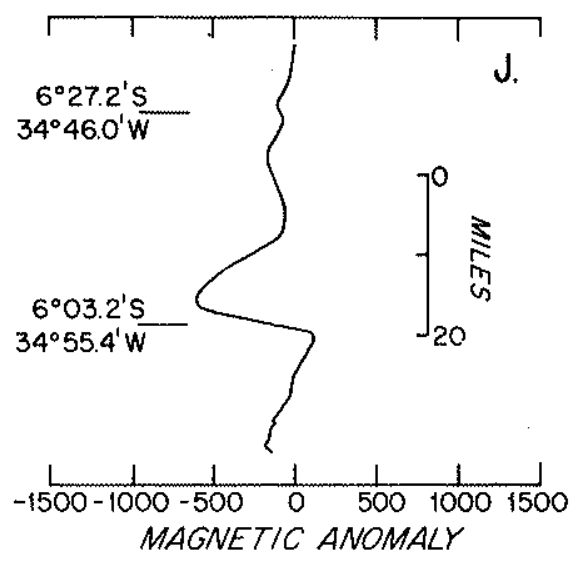

LINE 143 (Amazon Area)

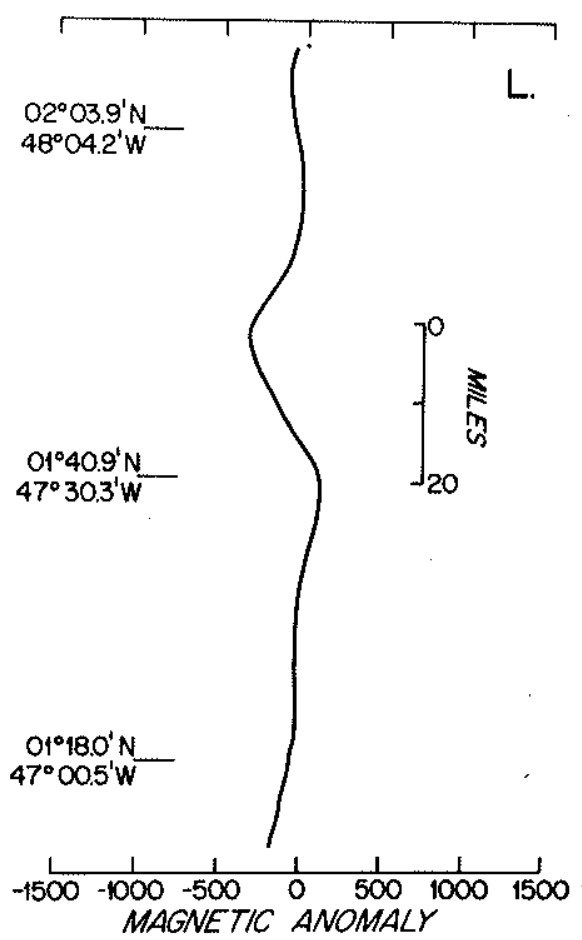

Figure 9 - Magnetic anomaly profiles off northern Brazil

correlate to the eastern and western Mexiana grabens of Rezende and Ferradaes (1971), although the actual relation between the landward grabens and shelf anomalies is not clear. Presumably this horst-graben feature predates the rifting of South America from Africa, as it is found on the shelf off Liberia (Behrendt et al., 1973), which corresponds with the Amazon shelf anomalies in the reconstruction of South America and Africa (Bullard 


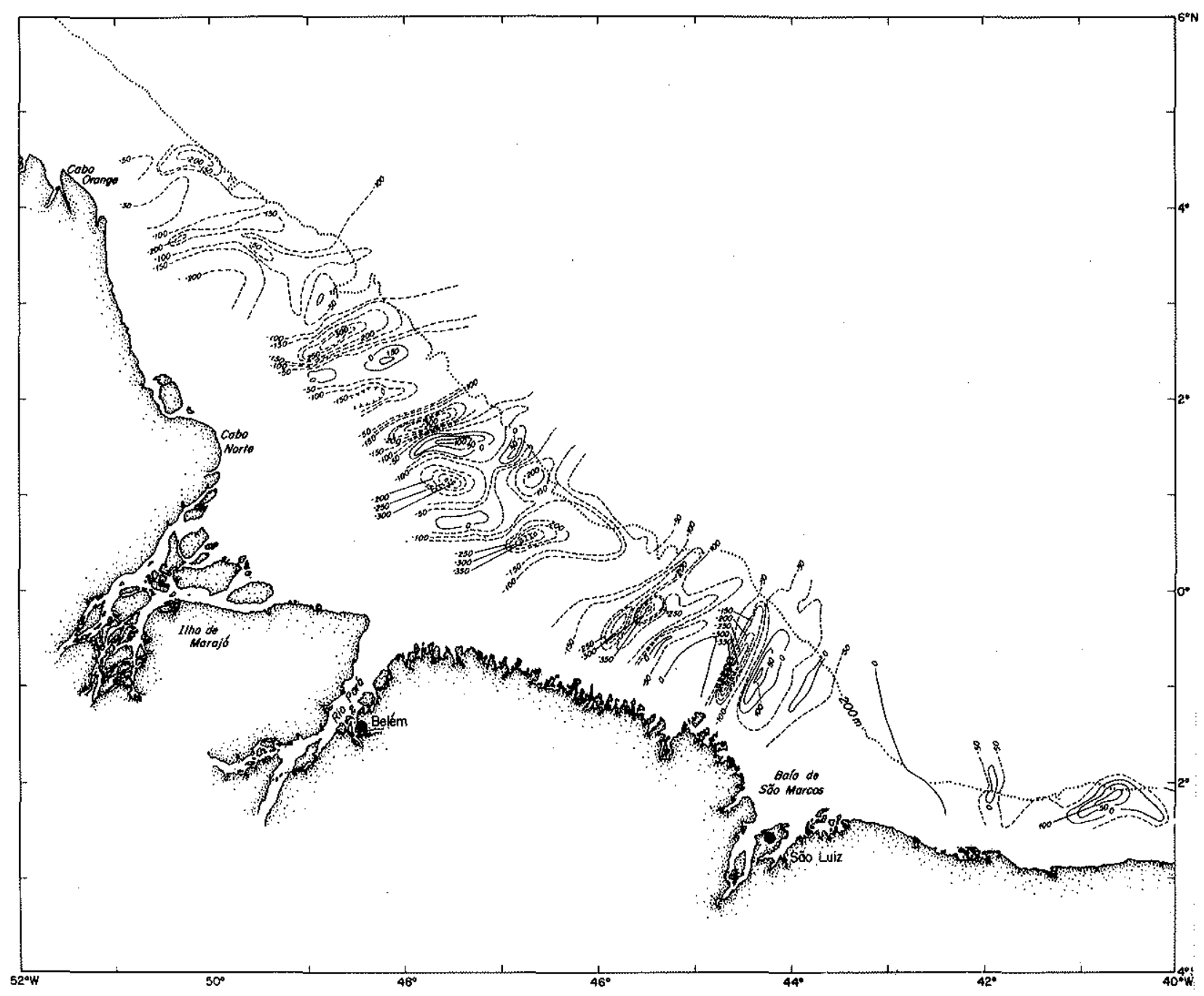

Figure 10 - Magnetic anomalies (in gammas) off northwestern Brazil

et al., 1965). Another indication of the age of these anomalies is the fact that they do not extend significantly beyond the upper slope; seaward anomalies in this area tend to run parallel to the shelf rather than perpendicular to it (Cochran, 1973).

CONCLUSIONS The collection of a substantial body of geomagnetic data from the continental margin of Brazil allow us to make some general statements about the structures of the shelf and upper slope over much of the area. In general the magnetic pattern of the continental shelf indicates continuation beneath the shelf of structures delineated on land. This applies both to areas of broad uplift and coastal sedimentary basins. The magnetic character of the slope and the marginal banks and plateaus, however, is usually different from this continental pattern, reflecting the influence of oceanic processes and structures. Oceanic fracture zones and seamounts are only two examples of oceanic structures which merge onto the continental margin. 
Acknowledgements This study was sponsored by the government of Brazil through a contract to Woods Hole Oceanographic Institution from Petroleo Brasileiro S/A. We thank D. E. Koelsch and N. Ferrari for their help in perfecting shipboard techniques, C. Rogers for helping with computer analyses and C. P. Summerhayes and E. Uchupi for their critical reading of the manuscript.

\section{REFERENCES}

BEHRENDT, J. C., SCHLEE, J., and ROBB, J. M. - 1974 - Geophysical evidence for the intersection of the St. Paul, Cape Palmas and Grand Cess Fracture Zones with the continental margin of Liberia, West Africa. Nature, 248: 324-326

BULLARD, E. C., EVERETT, J. E., and SMITH, A. G. - 1965 - The fit of continents around the Atlantic. Symposium on Continental Drift. Royal Soc. London Philos. Trans. Ser. A, 258: $41: 51$

GAIN, J. G., DANIELS, W. E., HENDRICKS, S. J., and JENSEN, D. C. - 1965 - An evaluation of the main geomagnetic field. Jour. Geophys. Res., 70: $3647-3674$

CAIN, J. C., HENDRICKS, S. J., DANIELS, W. E., and JENSEN, D. C. - 1964 - Computation of the main geomagnetic field from spherical harmonical expansions. NASA X-611-64-316

COCHRAN, J. R. - 1973 - Gravity and magnetic investigations in the Guiana Basin, western Equatorial Atlantic. Geol. Soc. Amer. Bull., 84: 3249-3 268

Departamento Nacional da Produção Mineral (DNPM) - 1971 - Mapa Tectônico do Brasil

FRANCHETEAU, J., and LE PICHON, X. - 1972 - Marginal fracture zones as structural framework of continental margins in the Atlantic Ocean. Amer. Assoc. Petrol. Geol. Bull., 56: $991-1007$

International Association of Geomagnetism and Aeronomy (IAGA) - Commission 2, Working Group 4-1969 - International Geomagnetic reference field 1965.0. Analysis of the Geomagnetic field. Jour. Geophys. Res., 74: 4407

REZENDE, W. M. de, and FERRADAES, J. O. - 1971 - Integração geológica regional da bacia sedimentar da Foz do Amazonas. An. XXV Gongr. Bras. Geol., 3: 203 314

SCHALLER, H., VASCONCELOS, D. N., and CASTRO, J. G. - 1971 - Estratigrafia preliminar da bacia sedimentar da Foz do Rio Amazonas. An. XXV Congr. Bras. Geol., 3: 189-202 